DOI: $10.19195 / 0137-1134.114 .28$

\author{
ANDRZEJ BORKOWSKI \\ Uniwersytet Wrocławski \\ andrzej.borkowski@uwr.edu.pl
}

\title{
STRUKTURA PRAWNA NADZORU NAD REGULOWANA DZIAŁALNOŚCIĄ GOSPODARCZĄ
}

\begin{abstract}
Abstrakt: Artykuł został poświęcony szczególnemu charakterowi prawnemu nadzoru, stanowiącego wyraz reglamentacyjnej funkcji państwa w stosunku do regulowanej działalności gospodarczej. Przedsiębiorcy wykonujący tę działalność podlegają nadzorowi ze strony organów prowadzących rejestry działalności regulowanej. Nadzór nad tą działalnością ma charakter ciągły. Decyzja o zakazie wykonywania działalności regulowanej powinna być następstwem stwierdzenia, że jej wykonywanie stanowi naruszenie przepisów prawa materialnego. Nadzór jest więc ściśle związany z badaniem zgodności z prawem wykonywanej działalności. Kompetencja w zakresie sprawowania nadzoru, przysługująca organom prowadzącym rejestr, służy realizacji celu nadzoru, którym jest zapewnienie, że przedsiębiorcy wykonujący działalność regulowaną będą przestrzegać przypisanych prawem warunków. Celem nadzoru nie jest ograniczanie dostępu do wykonywania działalności gospodarczej w typowy sposób, polegający w szczególności na ustanawianiu wymogu uzyskania zezwolenia na wykonywanie pewnych rodzajów działalności — nie jest zatem jego celem określanie, ilu przedsiębiorców będzie mogło funkcjonować na rynku w poszczególnych sektorach gospodarki.
\end{abstract}

Słowa kluczowe: regulowana działalność gospodarcza, nadzór, rejestr działalności regulowanej, przedsiębiorca

1. Społeczna gospodarka rynkowa wyznacza rolę państwa w gospodarce, określoną zasadami państwa prawnego. Formułuje cele państwa, wywierając wpływ także na charakter jego funkcji wykonywanych przez administrację publiczną w gospodarce.

Normatywna treść art. 20 Konstytucji Rzeczypospolitej Polskiej oznacza zobowiązanie państwa do podejmowania działań łagodzących społeczne skutki funkcjonowania praw rynku przy pełnym poszanowaniu tych praw ${ }^{1}$.

Odpowiedzialność za bezpieczeństwo socjalne i realizację dobra wspólnego nie zwalnia oczywiście państwa z odpowiedzialności za dynamiczny rozwój

${ }^{1}$ L. Garlicki, Polskie prawo konstytucyjne, Warszawa 1997, s. 105. 
gospodarczy ${ }^{2}$. Wykonanie tych zadań wymaga ukształtowania stosownych kompetencji i wyposażenia w nie organów administracji publicznej, umożliwiając im korygowanie praw rynku w celu realizacji określonych potrzeb społecznych, niemożliwych do spełnienia w ramach swobody rynku.

Korygujący charakter funkcji państwa - jak stwierdza L. Kieres - oznacza nie tylko przyjmowanie odpowiednich instytucji prawnych. Powinny one również prowadzić do nadania społecznej gospodarce rynkowej wymiaru realnego poprzez zapewnienie gospodarce zdolności funkcjonowania. Z treści zasady wolności gospodarczej, jak dalej stwierdza badacz, wywodzimy postulat o charakterze dyrektywy adresowanej do władz publicznych o równe traktowanie podmiotów, które charakteryzują się w danej sytuacji tymi samymi elementami. Jednak z zasady wolności wynika także obowiązek traktowania adresatów aktów władz publicznych w sposób zróżnicowany przez uwzględnienie ich zdywersyfikowanej sytuacji ${ }^{3}$.

Stwierdzenie to znajduje oparcie w ukształtowanym systemie prawa. Funkcjonowanie przedsiębiorców w systemie wolnej działalności gospodarczej i działalności reglamentowanej jest oczywiście zróżnicowane. Konstatacja ta odnosi się w szczególności do zakresu ingerencji państwa wobec przedsiębiorców w trakcie wykonywania przez nich działalności gospodarczej. W nie mniejszym jednak zakresie dotyczy podmiotów nieuczestniczących w obrocie gospodarczym, a zamierzających podjąć działalność gospodarczą, której wykonywanie uzależnione jest (w mniejszym lub większym stopniu) od woli organów władzy publicznej wykonujących stosowne funkcje w realizacji swoich ustawowo wyznaczonych kompetencji ${ }^{4}$.

W systemie społecznej gospodarki rynkowej, gwarantującej realizację wolności gospodarczej, ingerencja administracji w swobodę podejmowania i wykonywania działalności gospodarczej powoduje w pełni uzasadnione zainteresowanie tą kwestią nauki publicznego prawa gospodarczego ${ }^{5}$. Zasady ogólne tego prawa

${ }^{2}$ B. Popowska, Kwalifikacja funkcji administracji w nauce publicznego prawa gospodarczego, [w:] Funkcje współczesnej administracji gospodarczej, red. B. Popowska, Poznań 2006, s. 67; K. Strzyczkowski, Rola wspótczesnej administracji w gospodarce (zagadnienia prawne), Warszawa 1992, s. 68.

${ }^{3}$ L. Kieres, Wolność działalności gospodarczej, [w:] System Prawa Administracyjnego, t. 8A. J. Grabowski, L. Kieres, A. Walaszek-Pyzioł, Publiczne prawo gospodarcze, Warszawa 2013, s. $111-112$.

4 A. Bator, Kompetencje w prawie i prawoznawstwie, Wrocław 2004, s. 36-38.

5 T. Kocowski, Reglamentacja działalności gospodarczej w polskim administracyjnym prawie gospodarczym, Wrocław 2009; A. Chełmoński, T. Kocowski, Reglamentacja działalności gospodarczej (problemy prawne), [w:] Instytucje prawne zarządzania państwowymi organizacjami gospodarczymi, red. K. Podgórski, Katowice 1985; K. Kiczka, Funkcje administracji gospodarczej jako przedmiot badań, [w:] Funkcje wspótczesnej administracji gospodarczej, s. 40-60; idem, Niektóre problemy prawne nadzoru administracyjnego w obszarze działalności gospodarczej, [w:] Nadzór administracyjny. Od prewencji od weryfikacji, red. C. Kociński, Wrocław 2006, s. 157-191; C. Kosikowski, Koncesje i zezwolenia na działalność gospodarcza, Warszawa 2002; M. Szydło, Kontrola 
dotyczą bowiem w szczególności ochrony przedsiębiorcy przed preponderancją władztwa publicznego poprzez określenie granic i sposobu jego zastosowania.

Nie zmienia to jednak faktu, że zasada wolności gospodarczej doznaje różnego rodzaju ograniczeń prawnych o charterze reglamentacyjnym ${ }^{6}$. Ingerencja państwa i jej intensywność uzależniona jest od zadań, jakie organom administracji wyznacza ustawodawca, co wynika $\mathrm{z}$ aksjologii przedmiotu ochrony przez ustawodawcę przyjętej. Uzasadnia to zróżnicowanie środków prawnych ingerencji państwa w gospodarkę. W nawiązaniu do nich przedmiotem rozważań niniejszego opracowania będzie próba wskazania uzależnienia intensywności ingerencji w swobodę podejmowania i wykonywania działalności gospodarczej, która jest wynikiem określonej struktury prawnej nadzoru, wykonywanego w obszarze tej działalności jako element reglamentacji gospodarczej. Ochrona właściwego funkcjonowania gospodarki rynkowej wykonywana jest bowiem przez państwo także poprzez sprawowanie funkcji nadzoru wobec podmiotów tej gospodarki, który umożliwia weryfikację dostępu i realizacji aktywności w zgodzie z ustawowo ukształtowanymi zasadami.

2. Regulowana działalność gospodarcza zaliczana jest do kategorii działalności reglamentowanej. Podlega swoistej ingerencji państwa uzasadnionej względami ochrony interesu publicznego. Stwierdzenie to jest uzasadnione pomimo powszechnego dziś uznawania tej kategorii działalności gospodarczej za formę będącą wynikiem liberalizacji dostępności wykonywania działalności gospodarczej. Wcześniej bowiem obecne kategorie działalności regulowanej były wyłączone z obszaru objętego wolnością gospodarczą poprzez poddanie ich reglamentacji, zazwyczaj w drodze wymogu uzyskania zezwolenia.

Wobec braku normatywnych desygnatów oraz pewnej różnorodności definicji reglamentacji występujących w literaturze przedmiotu na użytek dalszych rozważań przyjęta została ogólna definicja, uznająca reglamentację za funkcję państwa wobec gospodarki, polegającą na bezpośredniej ingerencji organów władzy publicznej w procesy gospodarcze. Celem owej ingerencji jest preferowanie interesu

koncesjonowanej działalności gospodarczej, „Studia Prawnicze” 2002, z. 3, s. 85-120; idem, Reglamentacja podejmowania działalności gospodarczej w nowej ustawie o swobodzie działalności gospodarczej, „Przegląd Ustawodawstwa Gospodarczego” (dalej: PUG) 2004, z. 12, s. 2-14; idem, Działalność gospodarcza regulowana, „Prawo Spółek” 2005, z. 1, passim; B. Walawski, Pozwolenia i koncesje w prawie polskim, Wilno 1939; M. Waligórski, Charakter prawny licencji na działalność gospodarcza, „Studia Prawnicze” 2003, z. 2, s. 103-124.

6 A. Chełmoński, Podstawowe zasady administracyjnego prawa gospodarczego, [w:] A. Borkowski et al., Administracyjne prawo gospodarcze, Wrocław 2009, s. 65; M. Waligórski, Regulowana działalność gospodarcza a zasada wolności gospodarczej. Tendencje rozwojowe?, [w:] 25 lat fundamentów wolności gospodarczej. Tendencje rozwojowe, red. J. Grabowski, K. Pokryszka, A. Hołdy-Wydrzyńska, Katowice 2013, s. 618. 
publicznego, rozumianego jako zabezpieczenie dóbr uznawanych powszechnie za wartości wymagające szczególnej ochrony ze strony państwa ${ }^{7}$.

Działalnością regulowaną objęte zostały te sfery (kategorie przedmiotowe) działalności gospodarczej, które ustawodawca uznał za wymagające ochrony i którą przepisy odrębnej ustawy wyraźnie określają jako działalność regulowa$n_{a}{ }^{8}$. Przedmiot tej działalności określają uregulowania właściwych ustaw szczególnych ${ }^{9}$, wskazujące jednocześnie warunki, których spełnienie jest konieczne do podjęcia przez przedsiębiorcę działalności gospodarczej kwalifikowanej jako regulowana. Nie jest zatem możliwe domniemanie co do kwalifikacji działalności gospodarczej jako regulowanej, albowiem uznanie za taką może mieć miejsce wyłącznie wobec jednoznacznego postanowienia zawartego w uregulowaniach ustawy szczególnej ${ }^{10}$. Normy zawarte w tych ustawach określają szczegółowo sytuację prawną podmiotów w płaszczyźnie dopuszczalnej ingerencji państwa oraz konieczności respektowania określonych obowiązków stanowiących warunki podjęcia tej działalności. Warunki te mogą być różnorodne, stanowione jako wymogi materialne oraz warunki formalne. Określenie sytuacji prawnej przedsiębiorcy następuje tu w sposób bezpośredni, wynika wprost z ustawy, w sposób niewymagający konkretyzacji w drodze czynności organu administracji publicznej. Konkretyzacji swej sytuacji prawnej przedsiębiorca dokonuje samodzielnie lub

7 Por. K. Kiczka, Prawne formy działania administracji gospodarczej $w$ działalności regulowanej, [w:] System Prawa Administracyjnego, t. 8A, s. 496; A. Chełmoński, T. Kocowski, op. cit., s. $47 \mathrm{n}$. Spośród wartości poddanych szczególnej ochronie należy wskazać porządek publiczny, bezpieczeństwo publiczne, zdrowie publiczne, cele polityki społecznej, ochrona konsumentów, system zabezpieczenia społecznego, utrzymanie równowagi finansowej, przeciwdziałanie nieuczciwej konkurencji, ochronę środowiska naturalnego i zabezpieczenie rzetelnego wymiaru sprawiedliwości. Wartości te są wymieniane jako szczególnie chronione zarówno w orzecznictwie krajowym, jak i Trybunału Sprawiedliwości Unii Europejskiej.

8 Art. 64 ust. 1 ustawy z dnia 2 lipca 2004 r. o swobodzie działalności gospodarczej (tekst jedn. Dz.U. z 2017 r. poz. 2168; dalej: usdg lub ustawa).

9 W odniesieniu do działalności gospodarczej reglamentowanej w trybie koncesji ustawodawca w postanowieniach usdg (art. 46) zamieścił pełen (zamknięty) katalog przedmiotowy koncesjonowanej działalności gospodarczej. Dodatkowo ustanowiono wymóg każdorazowej zmiany postanowień tej ustawy w wypadku wprowadzenia innych koncesji w dziedzinach działalności gospodarczej ponad te, które zostały w ustawie wymienione. Z kolei w przypadku działalności gospodarczej, której wykonywanie warunkowane jest uzyskaniem zezwolenia, ustawodawca w art. 75 usdg zawarł jedynie katalog otwarty, wskazujący ustawy, których regulacje odnoszą swe postanowienia do przedmiotu działalności, której podejmowanie jest możliwe na podstawie indywidualnego uprawnienia, uzyskiwanego w drodze aktu administracyjnego.

${ }^{10}$ Katalog tych ustaw nie został zamieszczony w przepisach usdg. Został natomiast wskazywany w literaturze; zob. R. Sowiński, Administracyjna reglamentacja działalności gospodarczej. Koncesje, zezwolenia, licencja i inne formy podobne, Wrocław 2006, s. 330 n.; Ustawa o swobodzie działalności gospodarczej. Komentarz, red. A. Powałowski, Warszawa 2007, s. 202 n.; A. Borkowski, Działalność gospodarcza regulowana (kilka uwag na tle reglamentacyjnej funkcji państwa), [w:] 25 lat fundamentów..., s. 107-108, C. Kosikowski, Ustawa o swobodzie działalności. Komentarz, Warszawa 2006, s. 42. 
poprzez interpretację treści zawartych w normie ${ }^{11}$. Tym samym w okolicznościach wskazanych w normach ustaw szczególnych, odnoszących się do konkretnego rodzaju działalności regulowanej, adresat może samodzielnie korzystać z formułowanych w niej uprawnień oraz realizować określone obowiązki. Uznanie przez przedsiębiorcę warunków podjęcia działalności za spełnione powoduje, iż staje się on beneficjentem publicznego prawa podmiotowego, uprawniającego do wykonywania działalności regulowanej w zdefiniowanym przedmiocie. Organ rejestrowy nie jest bowiem uprawniony do analizy (badania) wiarygodności oświadczenia złożonego przez przedsiębiorcę wraz z wnioskiem o rejestrację działalności gospodarczej regulowanej przed dokonaniem wpisu. Dokonuje sprawdzenia zgodności oświadczenia ze stanem faktycznym w trybie nadzoru, sprawowanego nad wykonywaną przez przedsiębiorcę działalnością gospodarczą. Powoduje to przeniesienie odpowiedzialności za ocenę spełnienia warunków podjęcia działalności regulowanej na samego przedsiębiorcę ${ }^{12}$.

Rola organu administracji publicznej ${ }^{13}$ jest $w$ tego typu regulacjach specyficzna. Polega na analizowaniu, obserwacji i kontroli zachowań podmiotów zobowiązanych i uprawnionych z mocy ustawy. Ewentualna interwencja organu następuje, gdy przedsiębiorca, realizując działalność gospodarczą, nie stosuje się do regulacji

11 Por. K. Kiczka, Administracyjnoprawne środki ksztattowania sytuacji prawnej przedsiębiorców, [w:] A. Borkowski et al., op. cit., s. 343-345.

12 Por. wyrok WSA w Lublinie z dnia 22 marca 2016 r., III SA/Lu 922/15, LEX nr 2046325.

13 Określenie ,organ administracji publicznej” odnoszone jest do wszystkich organów właściwych (uprawnionych z ustawy) w zakresie prowadzenia rejestru działalności regulowanej. Nie wszystkie organy rejestrowe są bowiem w istocie organami administracji w znaczeniu powszechnie przyjętym. Mają jednak taki charakter w świetle postanowień art. $5 \S 2$ pkt 3 k.p.a., zawierającego legalną definicję organu administracji, zgodnie z którą ilekroć w przepisach kodeksu jest mowa o organach administracji publicznej, rozumie się przez to ministrów, centralne organy administracji rządowej, wojewodów, działające w ich lub we własnym imieniu inne terenowe organy administracji rządowej (zespolonej i niezespolonej) oraz organy jednostek samorządu terytorialnego. W uregulowaniu art. 5 k.p.a. do organów administracji publicznej zaliczono także organy i podmioty wymienione $\mathrm{w}$ art. 1 pkt 2, czyli organy administracji publicznej w znaczeniu funkcjonalnym, a więc te, które z woli prawodawcy wyposażone zostały w kompetencje (lub nabyły je w drodze porozumień) do załatwiania spraw lub wydawanie rozstrzygnięć w drodze decyzji administracyjnych. Por. na ten temat A. Trela, Centralna Ewidencja i Informacja o Działalności Gospodarczej - próba oceny nowych rozwiazań prawnych. Zagadnienia wybrane, Poznań 2013, cyt. za: T. Kocowski, Postępowanie zwiazane z legalizacją działalności gospodarczej, podejmowanej przez osoby fizyczne, [w:] Swoistość procedur publicznego prawa gospodarczego, red. B. Popowska, Poznań 2013, s. 139. Katalog organów uprawnionych do prowadzenia rejestru działalności regulowanej formułują ustawy szczególne, odnoszące swe postanowienia do właściwej działalności gospodarczej. Pośród organów kompetentnych można wskazać między innymi ministrów, organy samorządu terytorialnego (starostów, marszałków województwa) oraz organy niektórych samorządów zawodowych (okręgowe rady lekarskie, okręgowe rady pielęgniarek i położnych). Ponadto inne uprawnione, na podstawie ustawy, organy, w tym na przykład Prezes Urzędu Komunikacji Elektronicznej i Prezes Narodowego Banku Polskiego. 
prawnej, której została ona poddana, bądź stosuje ją wadliwie ${ }^{14}$. Potencjalne władcze wkroczenie organu administracji publicznej nie następuje zatem w omawianej sytuacji na etapie dopuszczenia do wykonywania działalności gospodarczej, a podczas ,konsumowania” publicznego prawa podmiotowego, w trakcie prowadzenia przedmiotowej działalności. Prawidłowe interpretowanie oraz stosowanie prawa (warunków materialnych) przez przedsiębiorcę wykonującego określoną regulowaną działalność gospodarczą powoduje, że służy mu - wywodzone $\mathrm{z}$ istoty wolności działalności gospodarczej — roszczenie o zaniechanie ingerencji ze strony państwa ${ }^{15}$.

3. Przedsiębiorca, dla legalizacji działalności gospodarczej regulowanej, oprócz spełnienia wymogów materialnych, zobowiązany jest - na podstawie art. 64 ust. 1 usdg - do uzyskania wpisu w rejestrze działalności regulowanej. Złożenie przez przedsiębiorcę wniosku rejestrowego wraz z oświadczeniem o spełnieniu warunków materialnych powoduje, że właściwy organ rejestrowy, związany ustawą, ma obowiązek dokonania czynności rejestrowej, która konkretyzuje wobec przedsiębiorcy normę uprawniającą zawartą w ustawie szczególnej. $\mathrm{Z}$ istotnym jednak zastrzeżeniem, że owa indywidualizacja normy następuje nie $\mathrm{w}$ drodze decyzji (jak ma to miejsce $\mathrm{w}$ innych formach prawnych reglamentacji), a poprzez dokonanie czynności materialno-technicznej ${ }^{16}$. Upodabnia to czynność organu rejestrowego do wpisu w Centralnej Ewidencji i Informacji o Działalności Gospodarczej (CEIDG), dokonywanego w odniesieniu do swobodnej działalności gospodarczej. W tym zaś wypadku to nie wpis kreuje uprawnienie przedsiębiorcy do podjęcia określonej działalności, lecz powstaje ono z mocy samego prawa, a dokonana czynność ma charakter działania faktycznego organu administracji publicznej. Oznacza to, że jest ona nastawiona na wywołanie skutków faktycznych, a nie prawnych w sensie realizacji kompetencji o władczym charakterze. Odróżnia to czynności materialno-techniczne od klasycznie ukształtowanych prawnych form działania administracji ${ }^{17}$, które ze swej natury wywołują skutki prawne, polegające na powstaniu, zmianie lub zniesieniu uprawnienia bądź obowiązku. Istotą działań faktycznych jest ukształtowanie (na podstawie powszechnie obowiązujących norm prawnych) takiego stanu, który umożliwia przystąpienie do

14 A. Chełmoński, Typy norm materialnego prawa administracyjnego i ich rola $w$ ksztaltowaniu sytuacji prawnej jednostki, „Przegląd Prawa i Administracji” 167, 1972, s. 72-73.

15 A. Walaszek-Pyzioł, Swoboda działalności gospodarczej, Kraków 1994, s. 12.

16 Por. A. Chełmoński, T. Kocowski, op. cit., s. 297; M. Szydło, Działalność gospodarcza regulowana, s. 45; Z. Kmieciak, Czynności faktyczne administracji państwowej, „Studia Prawno-Ekonomiczne" 39, 1987, s. 73-74; M. Szydło, Reglamentacja podejmowania działalności gospodarczej..., s. 10-11.

17 A. Błaś, Prawne formy działania administracji publicznej, [w:] Prawo administracyjne, red. J. Boć, Wrocław 2010, s. 340-341. 
działań związanych ze stosowaniem środków prawnych ${ }^{18}$ motywowanych określonym celem.

Dążenie ustawodawcy do dalszej liberalizacji działalności gospodarczej stało się przyczyną uproszczenia i przyspieszenia procedur związanych z legalizacją regulowanej działalności gospodarczej. Dlatego też kompetencje organu administracji publicznej wykonującego zadania rejestrowe zostały ustanowione w zakresie ograniczonym do kontroli elementów formalnych wniosku, w szczególności jego kompletności, a nie zgodności podanych w nim informacji ze stanem faktycznym. Ewentualne stwierdzenie braków formalnych skutkuje wezwaniem przedsiębiorcy do ich uzupełnienia.

Podjęcie czynności władczej przez organ rejestrowy, przejawiające się w formie decyzji o odmowie wpisu do rejestru, możliwe jest na etapie postępowania rejestrowego wyłącznie w przypadkach zaistnienia, określonych w art. 68 usdg, przesłanek negatywnych. Dotyczy to sytuacji, gdy wobec przedsiębiorcy ubiegającego się o wpis zostało wydane prawomocne orzeczenie ${ }^{19}$ zakazujące wykonywania działalności gospodarczej objętej wpisem lub wcześniej wykreślono go $\mathrm{z}$ rejestru tej działalności z powodów uzasadniających wydanie decyzji o zakazie wykonywania przez przedsiębiorcę działalności objętej wpisem (art. 71 usdg). Konstrukcja art. 71 usdg nakłada na organ rejestrowy bezwzględny obowiązek wydania decyzji o odmowie wpisu do rejestru w sytuacji wystąpienia jednej z wskazanych przesłanek. Ustawodawca nie wyposażył jednak organu rejestrowego w kompetencje dające możliwość oceny (wartościowania) występującego stanu faktycznego, a jedynie zobowiązał go do dokonania subsumpcji, co powoduje, że decyzja owa ma charakter aktu deklaratoryjnego ${ }^{20}$.

Brak, co do zasady, uprzedniej (prewencyjnej) kontroli spełnienia ustawowych warunków szczególnych podjęcia określonej działalności regulowanej nie oznacza, jak słusznie zauważa K. Mełgieś21 ${ }^{21}$ że jej wykonywanie nie podlega weryfikacji, a pełną gwarancję ochrony interesu publicznego dają dobra wola, chęci i intencje przedsiębiorcy, zawarte w oświadczeniu o spełnieniu szczególnych, ustawowo wyznaczonych, warunków.

$18 \mathrm{Na}$ temat charakteru prawnego czynności materialno-technicznych administracji gospodarczej zob. K. Kiczka, Czynności materialno-techniczne administracji gospodarczej, [w:] System Prawa Administracyjnego, t. 8A, s. 592-594; Z. Kmieciak, op. cit., s. 73 n.

${ }^{19} \mathrm{Z}$ postanowień art. 68 usdg nie wynika, czy orzeczenie zakazujące wykonywania przedmiotowej działalności gospodarczej to orzeczenie sądu, czy też może to być orzeczenie innego uprawnionego organu, np. administracyjnego lub korporacji zawodowej. Musi być prawomocne i zawierać jednoznacznie sformułowany zakaz wykonywania działalności, o której wpis ubiega się przedsiębiorca w postępowaniu legalizacyjnym. Por. na ten temat R. Sowiński, Administracyjna reglamentacja działalności gospodarczej, Wrocław 2006, s. 327-328.

20 Por. M. Szydło, Działalność gospodarcza regulowana..., s. 45.

21 K. Mełgieś, Działalność regulowana jako forma reglamentacji wolności gospodarczej uwagi konstrukcyjne, „Studia Gdańskie” 7, 2010, s. 330. 
4. Przyjęte przez ustawodawcę rozwiązania istotnie ograniczające prewencyjne działania organu rejestrowego nie oznaczają oczywiście rezygnacji z wykonywania kompetencji nadzorczych. Organ prowadzący rejestr działalności regulowanej jest nie tylko organem rejestrowym, lecz — jak słusznie stwierdził Wojewódzki Sąd Administracyjny w Gliwicach ${ }^{22}$ — także organem, do którego zadań (i kompetencji) należy sprawowanie kontroli oraz nadzoru w zakresie wykonywania określonej działalności regulowanej.

Obowiązek nadzoru nad działalnością gospodarczą przedsiębiorców jest wynikiem ogólnej odpowiedzialności państwa za realizację ochrony interesu publicznego, esencją zaś celu nadzoru nad gospodarką, jak konstatuje K. Strzyczkowski ${ }^{23}$, są dobra lub interesy, które mają być chronione przez organy nadzorujące. Te właśnie wartości determinują treść działań nadzorczych podejmowanych wobec przedsiębiorców.

Współodpowiedzialność państwa za gospodarkę uznał także Trybunał Konstytucyjny, stwierdzając, iż społeczna gospodarka rynkowa „oznacza przyjęcie współodpowiedzialności państwa za stan gospodarki w postaci wymogu podejmowania działań, których celem jest łagodzenie społecznych skutków funkcjonowania gospodarki rynkowej. Treść działań realizujących ten cel, w konkretnych okolicznościach, winien jednak określić ustawodawca" 24 .

Dlatego też władcze działania organów administracji publicznej podejmowane na podstawie ustawowej wobec uczestników obrotu gospodarczego swobodnie działających w przestrzeni wyznaczonej im przez wolność gospodarczą, których przedmiotem jest ochrona interesu publicznego, określa się powszechnie nadzorem gospodarczym ${ }^{25}$. Jego cechą charakterystyczną jest sytuacja, w której organ nadzoru występuje w stosunkach zewnętrznych, opierając się na normach prawa materialnego ${ }^{26}$.

Działania władcze mają oczywiście charakter publicznoprawny i zawierają nakazy i zakazy skierowane wprost do przedsiębiorców, wskazujące im bezpośrednio sposób zachowania pożądany wobec regulacji prawnych zawierających

22 Wyrok WSA w Gliwicach z dnia 16 sierpnia 2016 r., III SA/Gl 628/16, LEX nr 2120744.

23 Por. K. Strzyczkowski, op. cit., s. 77.

24 Wyrok Trybunału Konstytucyjnego z dnia 30 stycznia 2001 r., K.17/00.

25 Por. T. Kocowski, Akty bieżacego nadzoru reglamentacyjnego, [w:] Środki prawne publicznego prawa gospodarczego, red. L. Kieres, Wrocław 2007, s. 71; R. Sowiński, O definiowaniu „,nadzoru” w prawie administracyjnym i prawie gospodarczym publicznym, [w:] Ksiega jubileuszowa z okazji 15-lecia Wydziału Prawa i Administracji Uniwersytetu Szczecińskiego, red. Z. Ofiarski, Szczecin 2004, s. 477.

${ }^{26}$ Wydaje się uzasadnione przypomnienie, że podstawą wyodrębnienia określonej funkcji administracji gospodarczej jest pewien kompleks przysługujących organowi kompetencji w powiązaniu z celami, których osiągnięciu ma służyć właśnie korzystanie z tych kompetencji. Zarówno cele, jak i służące ich osiągnięciu kompetencje określone są w sposób wyraźny przez ustawodawcę. Por. M. Strzelbicki, Funkcja reglamentacji a funkcja nadzoru gospodarczego, [w:] Konstytucyjna zasada wolności gospodarczej, red. W. Szwajdler, H. Nowicki, Toruń 2009, s. 407. 
normy kształtujące ${ }^{27}$. Owe normy kształtujące zawarte są oczywiście w ustawach szczególnych odnoszących swe postanowienia do określonej kategorii działalności regulowanej. Zespół tych norm stanowi dla przedsiębiorcy wzorzec postępowania (wymogów), jego zachowanie zaś lub stany faktyczne wynikające z tych zachowań niezgodne z tym wzorcem noszą znamiona bezprawności, powodujące przewidziane prawem konsekwencje.

Celem nadzoru jest spowodowanie, by zachowanie przedsiębiorców było zgodne z prawem, a zatem tworzącymi odpowiednie wzorce normami kształtującymi. Ustalenie stopnia zgodności zachowań przedsiębiorcy z prawem następuje poprzez podjęcie czynności stanowiącej pierwszy element ciągu działań tworzących nadzór bieżący. Elementem tym jest kontrola.

Ogólną podstawę kontroli spełnienia przez przedsiębiorcę warunków wymaganych do wykonywania działalności regulowanej stanowi przepis art. $70 \mathrm{usdg}$. Podmiotami kontroli są uprawniony organ i przedsiębiorca, treścią zaś prawa i obowiązki przedsiębiorcy oraz odpowiadające im kompetencje organów kontroli ${ }^{28}$. Jak stwierdza A. Chełmoński, organy powołane do prowadzenia kontroli, a także przedmiot i granice kontroli są — co oczywiste — tożsame z organami, przedmiotem i granicami nadzoru. Są one więc określone w przepisach powołujących organ nadzoru oraz przepisach materialnoprawnych, które określają wzorzec zachowań podmiotów nadzorowanych, a więc w normach kształtujących ${ }^{29}$.

Organem właściwym do wykonywania kontroli w odniesieniu do działalności regulowanej ustawodawca uczynił — w szczególności — organ prowadzący rejestr danej działalności. Użycie zwrotu „W szczególności” sugeruje, że oprócz organu rejestrowego mogą takie kompetencje mieć również inne organy. Takie rozszerzenie kompetencji kontrolnych zdaniem C. Kosikowskiego jest uzasadnione obowiązkiem spełniania przez przedsiębiorcę (oprócz warunków wykonywania działalności regulowanej) uniwersalnych warunków, odnoszonych do każdej działalności gospodarczej, w tym warunków policyjnych ${ }^{30}$. W konsekwencji umożliwia to wykonywanie kontroli w stosownym zakresie, także przez właściwe w tym obszarze organy.

Należy ponadto zauważyć, że organy prowadzące rejestr działalności gospodarczej regulowanej nie stanowią — jak już wskazano — kategorii jednolitej. Kompetencje organów rejestrowych w zakresie kontroli oraz nadzoru są szczegółowo określone w drodze postanowień ustawowych. Wynikają z uregulowań prawa materialnego, odnoszących się do określonej kategorii działalności regulowanej.

27 A. Chełmoński określa normami kształtującymi te, które stanowią fragment otoczenia prawnego przedsiębiorstwa, a ich skutkiem jest ustanowienie pewnego wzorca postępowania przedsiębiorcy, wymaganego z punktu widzenia interesu publicznego. Zob. A. Chełmoński, Nadzór policyjny i reglamentacyjny w administracyjnym prawie gospodarczym, [w:] A. Borkowski et al., op. cit., s. 517.

28 Ibidem, s. 519.

29 Ibidem, s. 519-520.

30 C. Kosikowski, Ustawa o swobodzie działalności..., s. 304. 
Ustalają przedmiot, warunki i granice kontroli, jednakże niekiedy w swych postanowieniach wprowadzają regulacje umożliwiające rozdzielenie funkcji kontrolnej od nadzoru. Jest tak, gdy z woli ustawodawcy organ rejestrowy może upoważnić do podjęcia czynności kontrolnych inny organ państwowy lub państwową jednostkę organizacyjną wyspecjalizowaną w kontroli danego rodzaju działalności ${ }^{31}$. W tej sytuacji czynności materialno-techniczne zmierzające do ustalenia na obszarze wyznaczonym przedmiotem kontroli stanu faktycznego ${ }^{32}$ wykonywane są przez podmiot, który nie jest wyposażony w kompetencje nadzorcze. Wówczas to akt pokontrolny zawierający wyniki podjętych czynności sprawdzających stanowi podstawę do odstąpienia od ingerencji przez organ nadzoru w wypadku niezaistnienia niezgodności stanu faktycznego z normą kształtującą bądź w sytuacji stwierdzenia nieprawidłowości - do podjęcia władczych działań nadzorczych w celu przywrócenia stanu zgodnego z prawem lub usunięcia skutków naruszenia prawa $^{33}$.

5. Wobec przedsiębiorcy wykonującego działalność regulowaną organem nadzoru zobowiązanym do podjęcia czynności władczej w formie decyzji administracyjnej o zakazie wykonywania działalności objętej wpisem jest, jak już wskazano, organ prowadzący rejestr tej działalności. Podjęcie decyzji o zakazie wykonywania przez przedsiębiorcę działalności jest rezultatem oceny dokonanej w ramach przeprowadzonej kontroli, która wykazała naruszenie warunków materialnych (zawartych w regulacjach szczególnych) wykonywania przedmiotowej działalności. Ogólną podstawę podjęcia decyzji stanowi przepis art. $71 \mathrm{usdg}$, zobowiązujący organ rejestrowy do podjęcia czynności w wypadku, gdy przedsiębiorca złożył oświadczenie o spełnieniu warunków koniecznych do wykonywania działalności regulowanej niezgodnie ze stanem faktycznym lub nie usunął naruszeń warunków wymaganych do jej wykonywania pomimo wcześniejszego wezwania ze strony organu. Ponadto do niezwłocznego wydania decyzji organ rejestrowy został zobowiązany po stwierdzeniu rażącego naruszenia przez przedsiębiorcę wa-

31 Por. ustawa z dnia 14 lipca 1983 r. o narodowym zasobie archiwalnym i archiwach (tekst jedn. Dz.U. z 2016 r. poz. 1506). Zgodnie z art. 51j organem prowadzącym rejestr działalności gospodarczej w dziedzinie przechowywania dokumentacji osobowej i płacowej pracowników jest marszałek województwa. Jako organ kontrolny może upoważnić, w drodze porozumienia, inny organ państwowy lub państwową jednostkę organizacyjną wyspecjalizowaną w kontroli danego rodzaju działalności. Natomiast zgodnie z ustawą z dnia 25 sierpnia 2006 r. o biokomponentach i biopaliwach ciekłych (tekst jedn. Dz.U. z 2017 r. poz. 285 ) organem prowadzącym rejestr działalności gospodarczej regulowanej w tym zakresie jest Dyrektor Generalny Krajowego Ośrodka Wsparcia Rolnictwa. Jest on jednocześnie organem wykonującym kontrolę i nadzór, a w świetle art. 29 ust. 8 kompetencje kontrolne dotyczące przestrzegania warunków działalności objętej wpisem może powierzyć innemu organowi administracji, który jest wyspecjalizowany w kontroli danego rodzaju.

32 M. Szewczyk, Nadzór w materialnym prawie administracyjnym, Poznań 1995, s. 43-44.

33 A. Chełmoński, Nadzór policyjny i reglamentacyjny..., s. 521. 
runków wymaganych do wykonywania działalności regulowanej ${ }^{34}$. Użycie przez ustawodawcę określenia wartościującego „rażące” naruszenie warunków powinno stanowić podstawę dokonania przez organ stosownych czynności ocennych (wartościujących), odnoszących się do naruszenia norm kształtujących ${ }^{35}$.

Powszechnie uważa się, że przesłanką wystąpienia rażącego naruszenia prawa jest oczywisty charakter tego naruszenia. W sposób rażący może zostać naruszony przepis, który może być stosowany w jednoznacznym (bezpośrednim) rozumieniu, to znaczy taki, który nie wymaga stosowania wykładni prawa. Rażące naruszenie prawa, co do zasady, może zatem wystąpić, gdy nie zastosowano się do jednoznacznie brzmiącej normy prawnej ${ }^{36}$. Jednakże trudno zaprzeczyć stwierdzeniu, iż zwrot ten należy do kategorii pojęć niedookreślonych, a więc wymagających wykładni ze strony organu decyzyjnego. Bezsporne jest oczywiście, że ocena wystąpienia przesłanki rażącego naruszenia prawa należy do organu rejestrowego. Niemniej jednak w wielu przypadkach dokonanie tej oceny jest o tyle ułatwione, że uregulowania szczególne wyraźnie wskazują, które naruszenia warunków materialnych mają charakter rażący ${ }^{37}$.

Dzięki przyjętemu przez ustawodawcę rozwiązaniu podstawę materialnoprawną decyzji nadzorczej o zakazie wykonywania określonej działalności regulowanej oraz o wykreśleniu przedsiębiorcy z rejestru stanowią normy wskazujące w sposób wyczerpujący przesłanki decyzji. Pozwala to na uznanie tych decyzji za decyzje związane. Jak uznaje A. Chełmoński, przemawia tu zatem cel nadzoru, jakim jest badanie zgodności zachowań przedsiębiorcy z normą kształtującą i w badaniu tym — z natury rzeczy — nie ma miejsca na własną inicjatywę organu wyrażającą się między innymi w instytucji uznania administracyjnego ${ }^{38}$.

34 Wojewódzki Sąd Administracyjny w wyroku z dnia 20 sierpnia 2014 r. uznał decyzję o zakazie wykonywania przez przedsiębiorcę działalności objętej wpisem, na podstawie art. $71 \mathrm{usdg}$, za decyzję mającą charakter sankcji administracyjnej (wyrok WSA w Warszawie, VI SA/Wa 3094, LEX nr 2149227).

35 Zob. J. Jendrośka, A. Adamiak, Zagadnienia rażacego naruszenia prawa w postępowaniu administracyjnym, „Państwo i Prawo” 1986, nr 1, s. 66-69.

36 Wyrok WSA w Gliwicach z dnia 11 maja 2015 r., III SA/G1 119/15, LEX nr 1754775.

37 Por. art. 45 ust. 2 ustawy z dnia 5 stycznia 2011 r. o kierujących pojazdami (tekst jedn. Dz.U. z 2016 r. poz. 627 z późn. zm.). Ustawodawca stanowi, że rażącym naruszeniem warunków wykonywania działalności gospodarczej w zakresie prowadzenia ośrodka szkolenia kierowców jest wielokrotne prowadzenie szkolenia w sposób niezgodny z wymaganymi warunkami przeprowadzania zajęć, w sposób niezgodny z programem szkolenia, pojazdami niespełniającymi wymagań, wielokrotne wystawianie niezgodnie ze stanem faktycznym zaświadczenia o ukończeniu szkolenia, a także odmowa poddania się kontroli. Rażącym naruszeniem warunków wykonywania działalności na gruncie ustawy z dnia 29 sierpnia 1997 r. o usługach turystycznych (tekst jedn. Dz.U. z 2017 r. poz. 1553) jest między innymi proponowanie klientowi zawarcia lub zawarcie umowy o imprezę turystyczną bez uprzedniego zawarcia umowy gwarancji bankowej lub ubezpieczeniowej, wykonywanie działalności poza terytorium określonym we wniosku, przyjmowanie od klientów wpłat z pominięciem rachunku powierniczego. Por. też M. Szydło, Działalność gospodarcza regulowana ..., s. 46.

38 A. Chełmoński, Nadzór policyjny i reglamentacyjny..., s. 525. 


\section{PODSUMOWANIE}

Analiza zarówno postanowień ustawy o swobodzie działalności gospodarczej odnoszących się do regulowanej działalności gospodarczej, jak i treści zawarte w ustawach szczególnych pozwalają stwierdzić, iż nadzór wykonywany przez właściwe organy w odniesieniu do tej kategorii działalności gospodarczej ma swoiste cechy wyróżniające. Nie budzi wątpliwości, że liberalizacja pewnych obszarów działalności, przez wyłączenie ich spod klasycznej reglamentacji i poddanie jej szczególnej regulacji w obrębie działalności regulowanej, nie spowodowała wyłączenia (zwolnienia) państwa z obowiązku ochrony gwarantowanych konstytucyjnie wartości, w tym ochrony interesu publicznego. Uproszczenie dostępu do wykonywania tej kategorii działalności gospodarczej nastąpiło bowiem przez rezygnację z celów prewencyjnych. Wymogi materialne, formułowane w ustawach szczególnych, kreują różne szczegółowe obowiązki prawne przedsiębiorców w zależności od rodzaju wykonywanej działalności regulowanej. To właśnie realizacja tych obowiązków stanowi przedmiot nadzoru bieżącego, wykonywanego przez organ rejestrowy wobec przedsiębiorców. Jego celem jest oczywiście korygowanie faktycznego wykonywania określonej działalności zgodnie z obowiązującymi regulacjami prawnymi kształtującymi wzorzec tej działalności. Taka konstrukcja nadzoru pozwala na uznanie go za nadzór gospodarczy. Zgodnie bowiem z przyjętymi w literaturze poglądami wyznacznikiem tej kategorii nadzoru jest ingerencja organów administracji publicznej podejmowana $\mathrm{w}$ interesie publicznym wobec podmiotów uczestniczących w rynku ${ }^{39}$, wykonujących zatem już określoną działalność gospodarczą. Nadzór ten nie obejmuje swym zasięgiem przedsiębiorców przed podjęciem działalności gospodarczej, a zatem nieuczestniczących w rynku. $\mathrm{W}$ tym bowiem obszarze mamy do czynienia $\mathrm{z}$ nadzorem prewencyjnym (zapobiegawczym). Celem tego drugiego jest kreatywne oddziaływanie na rynek przez dopuszczenie przedsiębiorcy do wykonywania działalności gospodarczej. Organ nadzoru w zakresie swych kompetencji uzyskuje możliwość kształtowania zakresu warunków, które w swej aktywności gospodarczej przedsiębiorca będzie musiał spełnić, gdyż od ich spełnienia uzależniona jest decyzja dopuszczająca go do wykonywania działalności. Ta cecha, jak można zauważyć, powoduje, że celem tego nadzoru jest realizacja funkcji reglamentacyjnej państwa. To zaś przenosi się na możliwość realizowania celów szczególnych mieszczących się w pojęciu polityki gospodarczej państwa. Ich realizacja wykracza poza przedmiot oddziaływania nadzoru gospodarczego. Sprawowany wobec przedsiębiorcy wykonującego działalność regulowaną ma na celu ochronę ważnego interesu publicznego przez „wymuszenie” spełnienia szczególnych warunków, wyznaczonych dla tej działal-

39 Por. T. Kocowski, Akty bieżacego nadzoru reglamentacyjnego..., s. 71. 
ności przez ustawodawcę. Nadzór ten pełni zatem funkcję służebną, umożliwiając skuteczną realizację funkcji reglamentacyjnej na etapie wykonywania działalności gospodarczej regulowanej.

\title{
LEGAL STRUCTURE OF SUPERVISION OVER REGULATED BUSINESS ACTIVITY
}

\begin{abstract}
Summary
This work contemplates the special legal character of supervision, which is as an expression of the rationing role of the state in relation to the regulated business activities. The supervision carried out by an administrative body which operates a register of regulated business activity is exercised over an entrepreneur who performs such regulated activity. The supervision is therefore of an on-going character. Any decision prohibiting the entrepreneur from performing regulated business activity should be a consequence of making an assessment that performance of such activity will breach the norms of the material law. The supervisory role is therefore particularly connected with verifying the legality of operating a business. The legal capacity to perform supervision vested with the registry bodies serves to fulfil the purpose of supervision. That purpose is to ensure the entrepreneurs will observe legal requirements for performing a particular regulated business activity. However, that purpose is not to ration the business activity in a typical manner, in particular through creatively doling out permits for performing specific activities, and therefore its purpose is not to decide how many entities may operate on the market in a given sector.
\end{abstract}

Keywords: regulated business activity, supervision, register of regulated business activity, entrepreneur

\section{BIBLIOGRAFIA}

Bator A., Kompetencje w prawie i prawoznawstwie, Wrocław 2004.

Błaś A., Prawne formy działania administracji publicznej, [w:] Prawo administracyjne, red. J. Boć, Wrocław 2010.

Borkowski A., Działalność gospodarcza regulowana (kilka uwag na tle reglamentacyjnej funkcji państwa), [w:] 25 lat fundamentów wolności działalności gospodarczej. Tendencje rozwojowe, red. J. Grabowski, K. Pokryszka, A. Hołdy-Wydrzyńska, Katowice 2013.

Chełmoński A., Nadzór policyjny i reglamentacyjny w administracyjnym prawie gospodarczym, [w:] A. Borkowski et al., Administracyjne prawo gospodarcze, Wrocław 2009.

Chełmoński A., Podstawowe zasady administracyjnego prawa gospodarczego, [w:] A. Borkowski et al., Administracyjne prawo gospodarcze, Wrocław 2009.

Chełmoński A., Typy norm materialnego prawa administracyjnego i ich rola $w$ ksztaltowaniu sytuacji prawnej jednostki, „Przegląd Prawa i Administracji” 167, 1972.

Chełmoński A., Kocowski T., Reglamentacja działalności gospodarczej (problemy prawne), [w:] Instytucje prawne zarzadzania państwowymi organizacjami gospodarczymi, red. K. Podgórski, Katowice 1985.

Garlicki L., Polskie prawo konstytucyjne, Warszawa 1997. 
Jendrośka J., Adamiak B., Zagadnienia rażacego naruszenia prawa w postępowaniu administracyjnym, „Państwo i Prawo” 1986, z. 1.

Kiczka K., Administracyjnoprawne środki kształtowania sytuacji prawnej przedsiębiorców, [w:] A. Borkowski et al., Administracyjne prawo gospodarcze, Wrocław 2009.

Kiczka K., Czynności materialno-techniczne administracji gospodarczej, [w:] System Prawa Administracyjnego, t. 8B. J. Grabowski, L. Kieres, A. Walaszek-Pyzioł, Publiczne prawo gospodarcze, Warszawa 2013.

Kiczka K., Funkcje administracji gospodarczej jako przedmiot badań, [w:] Funkcje współczesnej administracji gospodarczej, red. B. Popowska, Poznań 2006.

Kiczka K., Niektóre problemy prawne nadzoru administracyjnego w obszarze działalności gospodarczej, [w:] Nadzór administracyjny. Od prewencji od weryfikacji, red. C. Kociński, Wrocław 2006.

Kiczka K., Prawne formy działania administracji gospodarczej $w$ działalności regulowanej, [w:] System Prawa Administracyjnego, t. 8B. J. Grabowski, L. Kieres, A. Walaszek-Pyzioł, Publiczne prawo gospodarcze, Warszawa 2013.

Kieres L., Wolność działalności gospodarczej, [w:] System Prawa Administracyjnego, t. 8A. J. Grabowski, L. Kieres, A. Walaszek-Pyzioł, Publiczne prawo gospodarcze, Warszawa 2013.

Kmieciak Z., Czynności faktyczne administracji państwowej, „Studia Prawno-Ekonomiczne” 39, 1987.

Kocowski T., Akty bieżacego nadzoru reglamentacyjnego, [w:] Środki prawne publicznego prawa gospodarczego, red. L. Kieres, Wrocław 2007.

Kocowski T., Reglamentacja działalności gospodarczej w polskim administracyjnym prawie gospodarczym, Wrocław 2009.

Kosikowski C., Koncesje i zezwolenia na działalność gospodarcza, Warszawa 2002.

Kosikowski C., Ustawa o swobodzie działalności gospodarczej. Komentarz, Warszawa 2006.

Mełgieś K., Działalność regulowana jako forma reglamentacji wolności gospodarczej - uwagi konstrukcyjne, „Studia Gdańskie” 7, 2010.

Popowska B., Kwalifikacja funkcji administracji w nauce publicznego prawa gospodarczego, [w:] Funkcje wspótczesnej administracji gospodarczej, red. B. Popowska, Poznań 2006.

Sowiński R., Administracyjna reglamentacja działalności gospodarczej. Koncesje, zezwolenia, licencja i inne formy podobne, Wrocław 2006.

Sowiński R., O definiowaniu ,nadzoru” w prawie administracyjnym i prawie gospodarczym publicznym, [w:] Księga jubileuszowa z okazji 15-lecia Wydziału Prawa i Administracji Uniwersytetu Szczecińskiego, red. Z. Ofiarski, Szczecin 2004.

Strzelbicki M., Funkcja reglamentacji a funkcja nadzoru gospodarczego, [w:] Konstytucyjna zasada wolności gospodarczej, red. W. Szwajdler, H. Nowicki, Toruń 2009.

Strzyczkowski K., Rola wspótczesnej administracji w gospodarce (zagadnienia prawne), Warszawa 1992.

Szewczyk M., Nadzór w materialnym prawie administracyjnym, Poznań 1995.

Szydło M., Działalność gospodarcza regulowana, „Prawo Spółek” 2005, z. 1.

Szydło M., Kontrola koncesjonowanej działalności gospodarczej, „Studia Prawnicze” 2002, z. 3.

Szydło M., Reglamentacja podejmowania działalności gospodarczej w nowej ustawie o swobodzie działalności gospodarczej, „Przegląd Ustawodawstwa Gospodarczego” 2004, z. 12.

Ustawa o swobodzie działalności gospodarczej. Komentarz, red. A. Powałowski, Warszawa 2007.

Walaszek-Pyzioł A., Swoboda działalności gospodarczej, Kraków 1994.

Walawski B., Pozwolenia i koncesje w prawie polskim, Wilno 1939.

Waligórski M., Charakter prawny licencji na działalność gospodarcza, „Studia Prawnicze” 2003, z. 2.

Waligórski M., Regulowana działalność gospodarcza a zasada wolności gospodarczej. Tendencje rozwojowe?, [w:] 25 lat fundamentów wolności gospodarczej. Tendencje rozwojowe, red. J. Grabowski, K. Pokryszka, A. Hołdy-Wydrzyńska, Katowice 2013. 